\title{
Journalism and Politics in Bourdieuan Context: Newspaper Journalists' Metamorphosis
}

\author{
Nigar Degirmenci \& Ismet Parlak \\ Pamukkale University \\ E-mail: ndegirmenci@pau.edu.tr/iparlakepau.edu.tr
}

\begin{abstract}
In February 2011, Turkish police raided of the freedom of speech. In this paper, on OdaTV, accused of trying to launch a coup. Zaman newspaper did not evaluate it as an intervention against freedom of media. In December 2014, Turkish police raided the daily Zaman newspaper. At this point, Zaman newspaper wriwe will explain the differentiation of $\mathrm{Za}$ man newspaper's evaluation of the arrest of the journalists in 2011 and in 2014. The main frame of the study is also designed around the concepts of sociologist Bourdieu's terminology.
\end{abstract} ters evaluated this process as a violation

Keywords: habitus; journalism; politics; press.

\section{Introduction}

$\mathrm{T}$ HE contemporary Turkish political life era is a remarkable one as many developments both regionally and nationally are either reminiscent of a number of historical political events. Those political events have been represented via media to public in the frame of their political position. Each representation includes political perspectives, political interests and certain levels of propinquity to political power of those media agents. One of those political events was about OdaTv Media Group which has been having a strong opposite media discourse along with revealing secret political documents and recordings. In February 2011, Turkish police raided on OdaTV website and the homes of its owner and the journalists, and detained them, accused of trying to launch a coup against the government headed by Tayyip Erdogan in

Data de submissão: 2016-04-18. Data de aprovação: 2016-05-22. 
that time. That political event was evaluated as different as media group varieties in Turkey. Some of the media critics indicated that it was a violation on media freedom and an act of civic coup. On the other hand, especially right wing media was on favour of the arrests and, the political power, AKP and Erdoğan. One of those right wing media was the Zaman Newspaper which claimed it was a right and democratic thing to do. At the end of these vying arguments, the public opinion was divided into two main political poles.

Another historical political event occurred in December 2014. Turkish police raided the daily Zaman newspaper, detaining the editor-in-chief and the head of the newspaper's broadcaster. According to the prosecutor the detentions had been ordered on charges of founding and directing an armed terror organization, and being a member of this organization (Gülen Cemaati/ Gülen Movement). At this point, the Zaman Newspaper journalists assayed this intervention as a violation on the freedom of speech. The difference between the two discursive approaches on two different media interventions was not a result of the selfish understanding of "yes, if it happens to others", "no, if it happens to me", rather than that, it was a result of a profoundly changing political life, especially change in the dynamics between political power and Gulen Cult (and so Zaman Newspaper). In order to understand this change in political climate and its discursive results we look through Bourdieu's terminology: "Symbolic capitalAgents", "Space", "Habitus", and "Doxa"

\section{Method}

In order to examine the discursive differentiation, we collected 61 articles, published between 18/02/2011 and 06/03/2011, and 118 articles, published between 14/12/2014 and 14/01/2015. Those dates are chosen based on the political power's direct intervention on the media groups: OdaTv journalists' arrests happened in February 2011 and Zaman Newspaper journalists' arrests happened in December 2014. The Zaman Newspaper articles were scanned in terms of democracy and media, for those two different time periods. The newspaper's discursive metamorphosis comparatively explained through Bourdieu's terminology. 


\section{Theoretical Framework}

From the political power perspective, it is requisite to control public opinion via daily life practices, in order to reproduce its ideological discourses. Since media has an essential power in terms of defining not only what "true", "normal", "democratic" etc. but also what "false", "lie", "marginal" things are too, according to Bourdieu, this role of media is based on the inculcation, creating a real belief system consistently ensnaring and penetrating (Bourdieu, 2002: 24).

This requisition establishes an interactive relation between political power and media. This interactive relation between media and political power defines what it is worth to make the news and the content (positive or negative, neuter), how media should evaluate, in short, by the relation established framing effect occurs and each of these is a tool in terms of controlling public opinion. Thus, a society internalizes the speculative content about political life through media content which was structured in the frame of mutually interest relationship between media and political power. However, society is not only passively observing whatever media presents. As the media establish an interactive interest relation with political power, so do different society groups. The stronger relation between political power and the society groups, the stronger relation occurs between related media and the related society groups. So it could be evaluated as a triangle: Media, Political Power, and People. In the political power's perspective, the aim is to establish strong relation with those two, in order to keep power strong: if there is something wrong with one, it will affect the relation with the other, and this gets contagious till breaks the entire belief and trust system about the political power. Eventually it will cost power itself.

The role of media in the reproduction of political power's discourse is a trump in its relation with political power, however this trump may also be a weapon which fires back. Political power has been and always will be requiring to control it; when it cannot, the interactive relationship based on mutual interest will be redefined. Bourdieu (2000: 87) points out that even there seems a competitive relation between agents of political champ's and journalist champ's, journalistic champ is surrounded by political champ which was affected by journalistic champ. Moreover, both champs are directly and strictly under pressure of the market's and public opinion's enforcements. Thus, jour- 
nalist champ's pressure power is formed through hegemonic power's control. Bourdieu's theory of practice is developed in three main analytical concepts: habitus, fields (Champ) and capitals. In this paper we aim to scrutinize the discursive change in the Zaman newspaper articles between 2011 and 2014 related to democracy and media freedom by guiding Bourdieu's terminology that he used to analysis the effects of political and media champs on each other's.

From all concepts, habitus has a priority. According to Bourdieu, (1996: 101) "...the unity hidden under the diversity and multiplicity of the set of practices performed in fields governed by different logics and therefore inducing different forms of realization, in accordance with the formula: [(habitus) (capital) $]+$ field = practice." In this respect, Bourdieu $(1989: 14,17)$ defines habitus as "schemes of perception, thought. and action", and claims that "...the affinities of habitus experienced as sympathy or antipathy, are at the basis of all forms of cooptation, friendships, love affairs, marriages, associations..."

...habitus produces practices and representations which are available for classification, which are objectively differentiated... Habitus thus implies a "sense of one's place"but also a "sense of the place of others. (Bourdieu, 1998a: 19).

According to Bourdieu, habitus is not only producer of actions and reactions but also a result of adaptation to social environment in the process of personal development. Thus, internalized habitus is in favour of status quo and tends to keep the person in adapted conditions.

In this respect, habitus can be evaluated as a product of internalization of structures of the social world. When there is an alteration in a capital, there should be also alteration in this internalization process as well and vice versa. Bourdieu (1996: 110) notes that “.... when the practices generated by the habitus appear as ill-adapted because they are attuned to an earlier state of the objective conditions (this is what might be called the Don Quixote effect)." Thus habitus is expected to recapitulates one's belief system and when there is a gap, the belief system dramatically collapses.

The presence of the past in this kind of false anticipation of the future performed by the habitus is, paradoxically, most clearly seen when the sense of the probable future is belied and when dispositions ill-adjusted to the objective chances because of a hysteresis 
effect (Marx's favourite example of this was Don Quixote) are negatively sanctioned because the environment they actually encounter is too different from the one to which they are objectively adjusted (Bourdieu, 1990:62)

What makes people have different habitus then? Bourdieu at this point develops more concepts such as; capitals, champs. According to him, there are different capital i.e. economic capital, cultural capital, symbolic capital, social capital. Bourdieu (1989:17) claims that:

these fundamental powers are economic capital (in its different forms), cultural capital, social capital, and symbolic capital (...) are distributed in the overall social space, in the first dimension, according to the overall volume of capital they possess and, in the second dimension... according to the structure of their capital, that is, the relative weight of the different species of capital, economic and cultural, in the total volume of their assets.

Media space is surrounded by political space, and political space is surrounded by social struggle and competitive environment which is based in power balance. According to Kaya, actors in this space try to keep or change this balance with their capitals. (Kaya, 2010: 416) As a results, new conditions occur and this new conditions require the organisms' adaptation to them. At this point we can see habitus is how much vital concept. Indeed habitus will provide the new framework for new trends to be transformed to adapt to current conditions.

According to Bourdieu (1989:17,21) "symbolic capital is the form that the various species of capital assume when they are perceived and recognized as legitimate" and "symbolic relations of power tend to reproduce and to reinforce the power relations that constitute the structure of the social space." And he continues (1989:21,23):

In the symbolic struggle for the production of common sense or, more precisely, for the monopoly over legitimate naming, agents put into action the symbolic capital that they have acquired in previous struggles and which may be juridical guaranteed...Symbolic capital is a credit; it is the power granted to those who have obtained sufficient recognition to be in a position to impose recognition. In this way, the power of constitution 
Thus, symbolic capital is in common perceptions and in this context, in 2011 being a journalist member of Zaman newspaper (as a part of the jamaat) which is in a relation based on mutual interest and common weltanschauung, is a symbolic capital. However in 2014, by the broken relation between AKP government and the jamaat is no longer avoidable, even the journalists are still Muslim and conservative, their being member of a conservative Zaman newspaper is no longer a symbolic capital. Those journalists who lost their symbolic capitals, are no longer identify themselves as speakers of AKP, especially not of. Erdogan. In this paper we evaluate the break between the newspaper (The Gulen Cult in particular) and the political power, as a dramatic and deep change in their capitals. In this paper, this radical change will be evaluated as Zaman newspaper journalists' discursive metamorphosis from opinion technician (Doxosophne) to victim journalists.

Bourdieu (1998a: 15-16) borrowing the term from Plato and uses as Doxosophne. Bourdieu sums up the meaning as 'a technician of opinion who consider themselves as wise people'. According to Bourdieu (2006: 17) they are so-called experts, speaking about the political problems in a same way with politicians and businessmen. Bourdieu (2013: 24) claims that they have some kind of glasses which let them see something and not see the rest, when they see something they see it in a very specific way. Most importantly, those glasses are framed by the political power.

Opinion technicians, on behalf of guaranteeing the continuity of the established political order, to be required to repeat the arguments which are produced by power, until they become acceptable in public. ${ }^{1}$ Technicians of opinion always position themselves according to political powers ' interest and discourses, therefore, they are a kind of "negative intellectual'. 'Their abilities to opposite, to rebel, to resist, and to demonstrate are entirely diminished " and; 'they do not hesitate 'to take the lead role in the manipulative operations. Because they are " in the position of the symbolic power" (Alban, 2014: 19). The biggest contribution they make is degenerating the opposition against the government, simplifying, providing the absurdity or banalizing them. On the other hand political powers defend their own acts as an absolute right, expect the same from both the media and from society. However Bourdieu believes

1. In Bourdieu's perspective the order which is guaranteed by technicians of opinion is neoliberal one but in this paper we uses the term of broader in a broader meaning. 
that there should be a distance between media and political champs. When there is not, there is an elusive form of democracy:

“...a perverse form of direct democracy can come into play when the media act in a way that is calculated to mobilize the public.... this "direct democracy"maximizes the effect both of the pressures working upon the media and of collective emotion." (Bourdieu, 1998b:64)

In short, Zaman newspaper's journalists' metamorphosis from doxaphsus to opposition can be evaluated like Bourdieu explains (Bourdieu, 1998b:64) "unable to maintain the distance necessary for reflection, journalists end up acting like the fireman who sets the fire".

Between 2011 and 2014 there is a recognizable change in Zaman newspaper journalists' discourse, with a sudden interest in media freedom, and according to Bourdieu (2006: 65), this change is not a coincidence, on the contrary it is a result of some struggles in change the rules of the game or keep as it is. Likewise, in 2011 the discourses of the journalists were a reflection of the government's one: focused on state; coup against to the AKP government by OdaTv and Military (Ergenekon); terror, terrorists.

Zaman newspaper had an attitude to create a common enemy in order to have a hegemonic power with AKP government (in the period of the government's alliance with the Jamaat). This conspirator perception is based creating common enemy; settling 'others ' to category of enemies and; placing 'foreigner powers' behind of all complot theories. But, this twisted strategy is not something unfamiliar to AKP, on the contrary. it was quite useful during the period of establishing 'New Turkey' by abolishing 'old Turkey' which was based on Ataturk's ideas.

As a kind of technician of opinion, the newspaper developed basic convictions formed in 2011 arrests can be summarized as follows:

1. From OdaTv, Şlk and Şener, even they have journalists identity they are convicted for plotting coup,

2. Formations illegal or antidemocratic are solely activated by 'old Turkey' and they are entirely restless by AKP's 'New Turkey'.

3. Mainstream media is recidivist. Their journalists work like a negative intellectuals, change the perception of the society in terms of the places of 'underdogs with tyrants', 'victims with murderers'. 
Zaman newspaper journalists justified the arrests in 2011 by indicating their being ordinary arrests. Also they claimed that those arrests could not be evaluated as abuse of freedom of press because they were not arrested because of their journalist actions but their undemocratic actions against to AKP government. In 2011 since there was not a crises between the government and the Jamaat, yet, it was quite clear for Zaman newspaper journalists what can be seen as undemocratic what can not be seen as freedom of press.

By the December $14^{\text {th }}$ arrests, Zaman newspaper which is now have to leave the role of technician of opinions' called for the support from journalists in Turkey and evaluated those arrests as against to freedom of press.

As will be noted, by the role of technician of opinion, there were "unlimited will to power, unlimited self-confidence, unlimited passion to say a word about everything" (Turk, 2012). They used discursive structures by criminalizing the opposite areas and actors, stigmatized them as 'ordinary guilty people'. Açıkel (2012: 19) evaluates them as 'a kind of coincidence engineering which is along with a suppressor political mind, making in all circumstances, its supporters winning, and its oppositions losing'. The newspaper worked effectively in order to find a scapegoat and has given almost every crisis' responsibility to 'Old Turkey'

The 'others' who are bad and prisoned in the term of 'Old Turkey', are mainstream media, CHP which is identified with coups and Ataturk, old military, old bureaucracy capitals from inside and outside. On the contrary the newspaper sees itself along with AKP government as a part of underdog subject group whose rights have been usurped for years. In terms of that Ş1k and Şener are not journalists but actors who characterize the enemy which is symbolised by 'Old Turkey 'metaphore. From now on, 'Old Turkey' members would no longer be able to do whatever they want in 'New Turkey'. According to newspaper, it is necessary to be vigilant against to the enemy because everything could be reversed. Turk $(2013 ; 2012)$ calls this as 'zombie reflex'. However in 2014, the only one is AKP who is running after a 'ghost enemy. 


\begin{tabular}{|c|c|c|}
\hline & What did the Zaman jounalists said in 2011 & What did the Zaman jounalists said in 2014 \\
\hline $\begin{array}{l}\text { Media freedom } \\
\text { and democracy? }\end{array}$ & $\begin{array}{l}\text { "Today's events (journalists' demand on } \\
\text { freedom rally) could be named as 'freedom of } \\
\text { events" only if we go to despotism not } \\
\text { democracy" (Bostanc1, 09.03.2011). } \\
\text { "Learning that all those dark things were done } \\
\text { under the cover of journalism is disgusting me } \\
\text { even more" (Kivanç, } 11.03 .2011 \text { ). } \\
\text { "Since when slandering, mediatic lynching, } \\
\text { reactionary campaigns are considered as } \\
\text { freedom of press?" (Kamiș, 26.03.2011). }\end{array}$ & $\begin{array}{l}\text { "Because we question that 'where Turkey is } \\
\text { going to', the raid will be remembered the most } \\
\text { dark day in our democratic history" (Kam1s, } \\
24.12 .2014 \text { ). } \\
\text { "In the leading article. Wall Street Journal } \\
\text { described those actions on silencing press and } \\
\text { opposite as another shameless step to move on } \\
\text { authoritarianism" (Aslan, 22.12.2014). }\end{array}$ \\
\hline $\begin{array}{lr}\text { Putting } & \text { into } \\
\text { action } & \text { the } \\
\text { principle } & \text { of } \\
\text { "Innocent until } \\
\text { proven guilty" }\end{array}$ & $\begin{array}{l}\text { "When you take a look at the document, you } \\
\text { can understand that how much OdaTv staff and } \\
\text { Ergenekonchefs have tried together in order to } \\
\text { build a public opinion" (Dumanll, 30.3.2011). } \\
\text { "Stop trying to exculpate the evidences in the } \\
\text { name of journalism. This is not journalism. Just } \\
\text { because you have word and pen, just because } \\
\text { you have a job which can criticize everyoneyou } \\
\text { do not consider yourself immaculate, Even if } \\
\text { you pretend, people will know" (Dağ, } \\
11.03 .2011 \text { ). }\end{array}$ & $\begin{array}{l}\text { "16 years old teenager is captivated, a } \\
\text { journalists who sent a tweet about 17th } \\
\text { December investigation is arrested. Journals } \\
\text { and Televisions are raided... a football team } \\
\text { fun club is prosecuted on attempted coup. The } \\
\text { article of reasonable suspicion" has been } \\
\text { applied on everyone. Half of the people have } \\
\text { become a semi-open prison" (Dumanl, } \\
05.01 .2015 \text { ). }\end{array}$ \\
\hline On police actions & $\begin{array}{l}\text { "There is no raid on OdaTv, they only came to } \\
\text { as a copy of the book... They [OdaTv } \\
\text { journalists] are exaggerating it" (Dumanl, } \\
28.3 .2011 \text { ) } \\
\text { "If there were no support for coups by the } \\
\text { media in the past, there would be no coup at } \\
\text { all... since that support is lost, in this country } \\
\text { coup is no longer something easy" (Dumanl, } \\
07.03 .2011 \text { ). }\end{array}$ & $\begin{array}{l}\text { "It's more than a scandal to take consideration } \\
\text { evidence collectedillegally. Such that thing was } \\
\text { not happened even in the } 28 \text { February process } \\
\text { [Military coup]" (Unal, 19.12.2014). }\end{array}$ \\
\hline $\begin{array}{l}\text { Is Turkey a state } \\
\text { of law and } \\
\text { democracy? }\end{array}$ & $\begin{array}{l}\text { "Everyobjective evidence indicatesthat Turkey } \\
\text { is more democratic and free country than in } \\
\text { past" (Bostanc1, 09.03.2011). } \\
\text { "Nedim Şener and Ahmet Şlk were arrested by } \\
\text { the evidence whichwere collected after the raid } \\
\text { on OdaTv" (Dumanl1, 4.4.2011) }\end{array}$ & $\begin{array}{l}\text { "Today AKP's Turkey is no longer state of law, } \\
\text { it is state of cuckoo... [He made a pun: State of } \\
\text { law: Hukuk devleti, State of cuckoo: Guguk } \\
\text { devleti, something nonsense]... The reason of } \\
\text { silence is known. Fair." (Unnal, 21.12.2014). }\end{array}$ \\
\hline $\begin{array}{l}\text { On arresting } \\
\text { press members }\end{array}$ & $\begin{array}{l}\text { "Those journalists are not evicted because of } \\
\text { theirjournalistactions. The crime attributed to } \\
\text { them is very grave: to be a member of } \\
\text { Ergenekon" (DEMIR, 17.03.2011). }\end{array}$ & $\begin{array}{l}\text { "We have been lowering our expectations with } \\
\text { state of law. We are not after luxuries such as } \\
\text { universal law. It is enough to rule out the rights } \\
\text { on the paper. We even crave for the } 1982 \\
\text { Constitution (which is ruled out after the coup). } \\
\text { At least do not mock with our intelligence" } \\
\text { (Korucu, 26.12.2014). }\end{array}$ \\
\hline $\begin{array}{l}\text { On the limit of } \\
\text { media/press } \\
\text { freedom? }\end{array}$ & $\begin{array}{l}\text { "Someone sank the needle on the balloon } \\
\text { which is full of pus and scattered mess of } \\
\text { tangledrelationships, showedhow a profession } \\
\text { is emasculated for the sake of an ideology" } \\
\text { (Hazar, 12.03.2011) }\end{array}$ & $\begin{array}{l}\text { "While our democracy has been evaporating, } \\
\text { thanks to God. There are still brave and } \\
\text { democratic intellectuals are taking risks and } \\
\text { speaks out. Many people from inside and } \\
\text { outside (from Turkish Journalists to Human } \\
\text { Rights Watch) has reacted to December } 14^{\text {th }} \\
\text { Coup on Media." (Bilici, 23.12.2014). }\end{array}$ \\
\hline $\begin{array}{l}\text { What is a coup, } \\
\text { who does it? }\end{array}$ & $\begin{array}{l}\text { "This broadcasting (OdaTv) who is love with } \\
\text { the military and directing them to coup, so to } \\
\text { speak, wind them up and give themselves to } \\
\text { those military powers as a gift "(Hazar, } \\
12.03 .2011)\end{array}$ & $\begin{array}{l}\text { "Come see Islamism as civil coup mentality." } \\
\text { (Kömeçoğlu, 15.12.2014). } \\
\text { "Political life in Turkey has been acted on } \\
\text { fiction enemies. We call it as fiction } \\
\text { because there is no evidence to keep people in } \\
\text { the prison who was arrested on claims as } \\
\text { "terrorist" or "coup" (Çetingüleç, 21.12.2014). }\end{array}$ \\
\hline
\end{tabular}




\begin{tabular}{|c|c|c|}
\hline $\begin{array}{l}\text { Who is in } \\
\text { partnership with } \\
\text { foreign powers? }\end{array}$ & $\begin{array}{l}\text { "You will see that an important part of them } \\
\text { will be having chats with foreigner press or } \\
\text { diplomats and will be striving to spread the } \\
\text { hostility of the government and the perception } \\
\text { (based on no knowledge) of Jamaat to } \\
\text { abroad"(Dumanl, 28.03.2011). } \\
\text { "First, they service their presumptuous and } \\
\text { stereotypical ideas to foreign broadcasts, and } \\
\text { then they are hiding behind some of the biggest } \\
\text { brands in Europe and Americaas if those ideas } \\
\text { were accepted by them. It is not journalism." } \\
\text { (Dumanl, 14.03.2011). }\end{array}$ & $\begin{array}{l}\text { "The operation on one of those powerful voices } \\
\text { of free media Zaman newspaper and Samanyou } \\
\text { Tv raised all democrats in Turkey and in the } \\
\text { World. This coup against on media is bad not } \\
\text { only for our writers and readers, watchers but } \\
\text { also for the integrity of our country" (Bilici, } \\
23.12 .2014 \text { ). } \\
\text { "Because of these Freedom House degraded } \\
\text { Turkey to the category of the countries where } \\
\text { media is not freedom" (Bilici, 23.12.2014). }\end{array}$ \\
\hline Who is the enemy & $\begin{array}{l}\text { "By sitting down at the dinner table of jackals } \\
\text { (Ergenekon), you can t be subjects of the king } \\
\text { (Erdogan) of the jungle" (Hazar, } 02.04 .2011) \\
\text { "The raison d'etre of being of hatred } \\
\text { columnists are based on the hostility of faith } \\
\text { and faithful" (Hazar, 02.04.2011) }\end{array}$ & $\begin{array}{l}\text { "Those who intend to build an autocratic } \\
\text { regimes argue that a coup attempt made } \\
\text { against them; that meanwhile made-up-coup } \\
\text { attempt is being suppressed, the obstacles of } \\
\text { establishing an authoritarian-autocratic } \\
\text { regimes would be removed". (Bulaç, } \\
15.12 .2014 \text { ). }\end{array}$ \\
\hline $\begin{array}{l}\text { Who is to be } \\
\text { humiliated }\end{array}$ & $\begin{array}{l}\text { "Some journalists whom I learnt name } \\
\text { recently..."(Alkan, 09.03.2011) } \\
\text { "Some people who award themselves as } \\
\text { journalists..." (Dumanl, 14.03.2011) } \\
\text { "...increasingly spreadingfoam of literature of } \\
\text { moaned journalists" (Alkan, 26.03.2011); } \\
\text { "some people who see themselves like The Pied } \\
\text { Piper of Hamelin"(Dumanl,, 28.03.2011); } \\
\text { "All around of us is full of vomit by allergic to } \\
\text { belief" (Hazar, 28.03.2011) }\end{array}$ & $\begin{array}{l}\text { "The coup on December 14th on Freedom was } \\
\text { badmouthed by the important articles in the big } \\
\text { newspapers in the US. President Erdogan's } \\
\text { behaviours were evaluated as paranoidtyranyy } \\
\text { in the leading article of New York Times. Times } \\
\text { mocked with the discourse of parallel state" of } \\
\text { Erdogan and call him as an authoritarian } \\
\text { leader who lives in a parallel universe"(Aslan, } \\
22.12 .2014 \text { ). } \\
\text { "American press "new toy is Erdogan, after } \\
\text { Ahmadinejad" (Aslan, } 15.12 .2014 \text { ) }\end{array}$ \\
\hline $\begin{array}{l}\text { Can people be } \\
\text { convicted and } \\
\text { right at the same } \\
\text { time? }\end{array}$ & $\begin{array}{l}\text { "Imagine a neighbourhood, there are serial } \\
\text { killers (Ergenekon)...everyday operate one } \\
\text { some people... They have media gun (OdaTv) } \\
\text { and keep firing to citizens...And one day a } \\
\text { prosecutor says to them 'stop"...Then those } \\
\text { start to scream as 'I'm scared" Why do you } \\
\text { even scare where the murderers are supposed } \\
\text { to be scared?"(Kamis, } 09.03 .2011 \text { ). }\end{array}$ & $\begin{array}{l}\text { "Since he read a poem, he went to prison, and } \\
\text { because he went to prison he gained political } \\
\text { power. Erdoğan will rediscover the power of } \\
\text { being prisoned and right" (Gültaşl, } \\
\text { 15.12.2014). }\end{array}$ \\
\hline $\begin{array}{l}\text { Freedom of } \\
\text { Justice }\end{array}$ & $\begin{array}{l}\text { "Some people who internalized the pressure } \\
\text { from the dark days of } 28^{\text {th }} \text { February, and even } \\
\text { more, were serving gladly as mouthpiece of the } \\
\text { [military] dictatorship, now are talking about } \\
\text { media freedom, opinion liberality" (Dumanl, } \\
28.03 .2011 \text { ). }\end{array}$ & $\begin{array}{l}\text { "The government who held capture the justice, } \\
\text { became a nightmare descending on the } \\
\text { country...Neitherprosecutor nor judge is free" } \\
\text { (Ayhan, 20.12.2014). } \\
\text { "There is no 'rule of law' principle in Turkey } \\
\text { anymore... many citizen's rights were usurped, } \\
\text { freedoms were threatened." (Keleș, } \\
20.12 .2014 \text { ). }\end{array}$ \\
\hline $\begin{array}{l}\text { On pressure on } \\
\text { media }\end{array}$ & $\begin{array}{l}\text { "Aiming to degenerate and discredit, they were } \\
\text { used to attempt to make corrode campaign all } \\
\text { together to targeted people or intuitions by } \\
\text { implying in order to do make them feel } \\
\text { insecure. You call thatjournalism? Don't make } \\
\text { me laugh!"'(K1vanc, } 11.03 .2011 \text { ). } \\
\text { "In the name of the freedom of press, there is a } \\
\text { choro which is trying to make a noise aiming to } \\
\text { silence everyone else's voice" (Gülerce, } \\
09.03 .2011\end{array}$ & $\begin{array}{l}\text { "The media was not under pressure like that } \\
\text { neither during military coup in } 1960 \text { nor in } \\
1980 \text { "(Ayhan, 20.12.2014). } \\
\text { "In a country where there is no law, it is even } \\
\text { harder to reach out to universal rights... The } \\
\text { hegemonic power, while was trying to silence } \\
\text { the media, does not comply with the law (which } \\
\text { is actually against to the universal rights) even } \\
\text { they rule out." (Türköne, 11.01.2015). }\end{array}$ \\
\hline $\begin{array}{l}\text { Who are the } \\
\text { targets? }\end{array}$ & $\begin{array}{l}\text { "Some people, especially President Gul, Prime } \\
\text { Minister Erdogan are targets of influence } \\
\text { agents... who denigrate those people and are } \\
\text { aiming to start legal process by lies and } \\
\text { slanders and by psychological warfare tactics" } \\
\text { (Dumanl, } 07.03 .2011 \text { ). } \\
\text { "... by saying it is 'freedom of press ' they are } \\
\text { trying to hit AK PARTY" (Gülerce, } 11.03 .2011 \text { ). }\end{array}$ & $\begin{array}{l}\text { "In this period, all jamaats are targets, they will } \\
\text { raise AKP's Muslim hood via religious } \\
\text { schools... and Erdogan will be remain as both } \\
\text { political and religion leader" } \\
\text { "This coup (on Jamaat's media) is not against } \\
\text { on only this media intuitions... From civic } \\
\text { society to politics, whoever has to be silent just } \\
\text { because of thinking differently" (Bilici, } \\
23.12 .2014 \text { ). }\end{array}$ \\
\hline
\end{tabular}




\begin{tabular}{|c|c|c|}
\hline $\begin{array}{l}\text { Who deceived } \\
\text { who? }\end{array}$ & $\begin{array}{l}\text { "When some journalists were arrested, some } \\
\text { part of the media raised hell. By making a flag } \\
\text { from "freedom of press", they told that as if } \\
\text { there were pressure on press... Turkey were } \\
\text { about to be a police state... etc." (Dumanl, } \\
07.03 .2011 \text { ). }\end{array}$ & $\begin{array}{l}\text { "The government members say "[Gülen] } \\
\text { Jamaat has tricked us', but actually we were } \\
\text { deceived." (Akman, 16.12.2014). } \\
\text { "As a faithful Muslim, brother Ekrem [Zaman } \\
\text { newspaper's arrested editor] did not deceive } \\
\text { but were deceived. How could he know that } \\
\text { Erdogan would become a person who is in } \\
\text { more favour of coups who was actually suffered } \\
\text { from couple of those" (Gültaşl1, 15.12.2014). }\end{array}$ \\
\hline $\begin{array}{l}\text { Non-democratic } \\
\text { media? } \\
\text { Mainstream or } \\
\text { partisan? }\end{array}$ & $\begin{array}{l}\text { "There are abundantly storyteller who were } \\
\text { believed in the mainstream" (Kivanç, } \\
13.03 .2011) \\
\text { "You awarded as journalists OdaTv working a } \\
\text { lies and slander machine and, someone who is } \\
\text { taking profession as character assassination, } \\
\text { and then you wanted them to be untouchables.., } \\
\text { You discredited this profession once more." } \\
\text { (Dağı, 11.03.2011). }\end{array}$ & $\begin{array}{l}\text { "So-called 'news channels' say that 'an } \\
\text { intervention on parallel structure' when } \\
\text { actuallypolices attemptedto raid the offices of } \\
\text { Zaman newspaper in the early morning." } \\
\text { (Dumanl, } 15.12 .2014 \text { ) } \\
\text { "No offence but the media of } 28 \text { th February } \\
\text { was far more conscientious than this partisan } \\
\text { media" (Hazar, 16.12.2014). }\end{array}$ \\
\hline $\begin{array}{l}\text { Where } \\
\text { democratic } \\
\text { person should } \\
\text { stand now? }\end{array}$ & $\begin{array}{l}\text { "A journalism which is not trustable with a } \\
\text { media (OdaTv) which does not work as a fourth } \\
\text { power are lost for Turkey" (Dağı, } 11.03 .2011 \\
\text { "The term of supporting anti-democratic } \\
\text { forces by dressing up injournalism armour has } \\
\text { already ended." (Dumanll, 14.03.2011). }\end{array}$ & $\begin{array}{l}\text { "Now it is a national debt to be opposite to the } \\
\text { AKP government who has 'middle } \\
\text { easternizated' Turkey by each passing day". } \\
\text { (Aslan, 15.12.2014). }\end{array}$ \\
\hline Any regrets? & & $\begin{array}{l}\text { "Oh I wish I said, would have come out to the } \\
\text { treatment to the erstwhile journalists and said } \\
\text { "Nay, no" would have given ear to those who } \\
\text { talk about civilian coup." (Akman, 16.12.2014). }\end{array}$ \\
\hline
\end{tabular}

Table 1. Comparative discourses from 2011 and 2014

As we can see from above the comparative discourse table, in 2011 articles, AKP government were identified with fight for 'democracy' and 'freedom' and also because of that AKP government was a victim, and on the other hand the arrested journalists were described as a worthless couple of people (not worthy to be journalists or even to have freedom) who attempted to coup against to AKP government. But, by 2014 arrests, as we can see from the right part of the table, AKP is the one who attempts to coup and cruel authority, and media (except the partisan media) is described as the victim of this subject"s (AKP government) brutal authoritarianism.

\section{Results}

The discursive metamorphosis period which lasted from 2012 to 2014 also created different evaluation about the newspaper from political power view. For example, by the transition from doxaphsus to opposition, political power started demonizing the newspaper by calling it "traitors"; "apostates"; "backsliders"...etc. By the relation between the political power and the jamaat was broken, Zaman newspaper's journalists were turning to falling angels. And 
this shows us a good example of what Bourdieu claims: journalists champ is under effect of political champs.

In this respect, we may expect that similar capital owners can have similar habitus'. When there is a radical change in one's capital, it reflects on the habitus as well. When it comes to journalism and politics relations and habitus/capital relation, it becomes clearer. Journalism can exist in a structure which is shaped by political champ (sphere). And habitus is a very useful concept to explore the discursive change of the journalists who can survive in political champs only by adapting to political environment, as an opposite or support. Such as reversing of interest relations with political power, under the special conditions, in order to cope with unexpected conditions people would require fundamental sources related to habitus (Tatlıcan and Çeğin, 2010: 316). According to Tatlıcan and Çeğin, habitus is also strategy productive principle which is based on our earlier experiences. (Tatlıcan ve Çeğin, 2010: 364, 317). Bourdieu claims (1998b:40-41):

All the individuals in this universe bring to the competition all the (relative) power at their disposal. It is this power that defines their position in the field and, as a result, their strategies. Economic competition between networks or newspapers for viewers, readers, or for market share, takes place concretely in the form of a contest between journalists... if I want to find out what one or another journalist is going to say or write, or will find obvious or unthinkable, normal or worthless, I have to know the position that journalist occupies in this space

The root of the word Doxasophus, doxa is unarguably accepted opinions in order to serve to a particular ideology. Thus doxa is a world of unquestionable strong beliefs (Mücen, 2010: 426). However, in an ideal world we must expect from journalists exactly the opposite of doxa, question everything. In the real world of 2011, Zaman newspaper journalists were used to be carriers of the opinion of political power until the corruption investigations against the AKP government between December $17^{\text {th }}$ and $25^{\text {th }}$ in 2013 and the particularly the arrests of them in December 14, 2014. After that, they have started to question everything which were doxa for them once. However, when we check the main reason of their starting question everything about political power, we can't see ideally journalists' motives but we see a dramatically 
change in their strategies which is shaped by their rooted habitus and interactive relations with political power. A radical change in one's symbolic capitals, reflects itself on one's habitus, and at that moment, adaptation process starts via new strategies which will help to keep habitus. In Zaman journalists' case, when they have lost their symbolic capital (which was gained by mutual interests with the political power), they also lost their doxasophus identity as well, and then they've become "ideal journalists", as questioning everything. In the following word clouds, we can observe the difference between the most used words in the examined articles from 2011 and 2014. This comparative table represents a change in their discursive strategies, for example, in 2011, the journalists have used frequently those words: "Ergenekon (the so-called 'Ergenekon' network has also been accused of operating as a "deep state" within the Turkish Armed Forces against to the political power); journalist; media; book (related to Ergenekon); crime; coup; psychological war; dark; court; CHP (opposition party). But in 2014, after the government acted on the Cult and arrested Zaman newspaper's journalists, their main words have changed to those: law, opposite; media; press; state.

As a consequently, the more crises or conflicts or polarization get deeper between the pieces of the hegemonic alliance around AKP government, "the lesser possibility to compromise on a common perception of the reality." (Gambetti, 2014) Because, evidences and accusations start to work on the relation which once a partnership. In 2011, when the OdaTv journalists were convicted, the hegemonic reality were built by the joint venture of AKP government, partisan media and Zaman Newspaper journalists. In 2014, when the Zaman newspaper journalists were convicted, the reality was divided into at least two opposite ones. In this time, Zaman journalists were against to the hegemonic partisan media discourse but actually in both convictions, there were two different and opposite reality were built by political power and opposition, replied the following questions fundamentally opposite: What is crime? What is democracy? Who is dictator? What is a coup, who does it? Where is the limit of media/press freedom? Can press member be arrested? What is law? Who acts on it? What is the content of freedom? A radical change in habitus makes journalists reply those kind of questions fundamentally different in order to make them adapt themselves to new conditions and, basically to the loss of their symbolic capitals. 


\begin{tabular}{|c|c|}
\hline 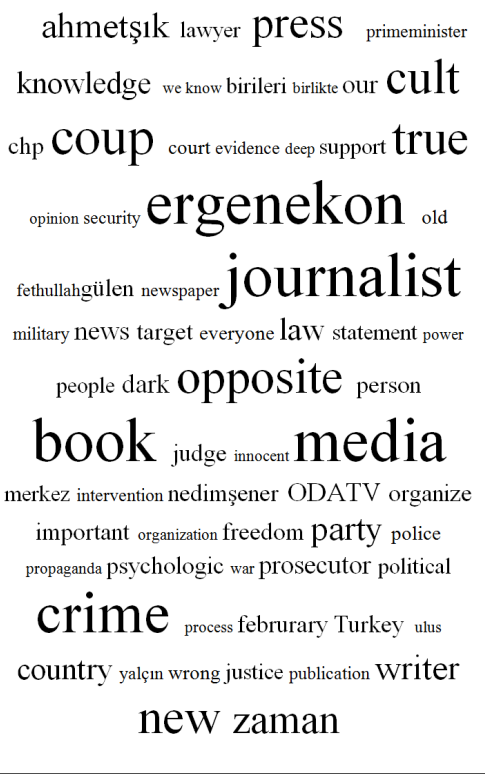 & 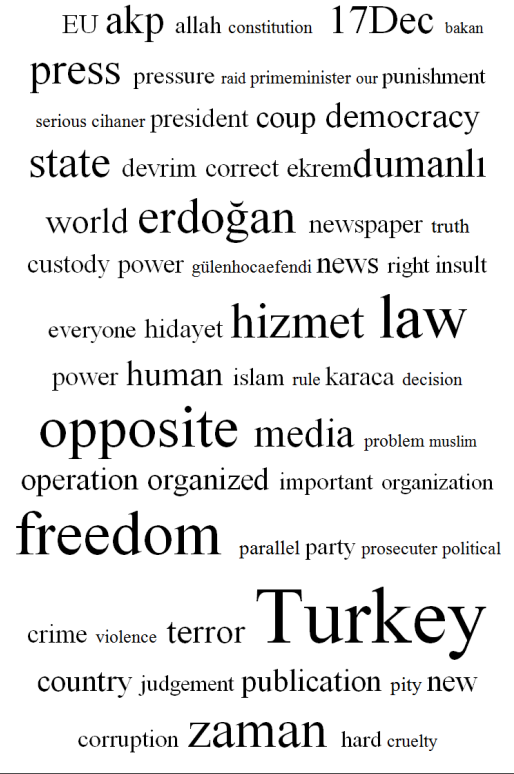 \\
\hline
\end{tabular}

Table 2. Comparative Word Clouds from 2011 and 2014

\section{Bibliography}

Açikel, F. (Nisan 2012). Muhafazakar Sosyal Mühendisliğin Yükselişi: 'Yeni Türkiye'nin Eski Siyaseti. Birikim, (276): 14-20.

Alpan, A. (2014). Çürürken Çürütüyorlar: 'Yeni Türkiye'nin Kanaat Teknisyenleri. Sol Dergi: 18-19.

Bourdieu, P. (1989). Social Space And Symbolic Power. Sociological Theory, 7(1): $14-25$.

Bourdieu, P. (1991, Mayıs 15). Doxa And Common Life, (Röportaj Yapan: T. Eagleton,) Londra.

Bourdieu, P. (1998). Contre-Feux. Paris: Raisons D'agir.

Bourdieu, P. (1998). On Television. New York: News Press.

Bourdieu, P. (2006). Karşı Ateşler. İstanbul: YKY. 
Bourdieu, P. (2013). Pratik Nedenler (Raisons Pratiques). (Çev. H. U. Tanrı̈ver), Hil Yayınları, Adıyaman.

Bourdieu, P. (2014). Seçilmiş Metinler, (Çev. L. Ünsaldı), Heretik Yayınları, Ankara.

Bourdieu, P. (2014, Bahar). Simgesel Sermaye Ve Toplumsal Sinıflar. Cogito, (76): 192-203.

Demir, E. (2014). 17 Aralık Ve Anti-Kapitalizme Reaksiyoner Düsmanlık. http://www.Birikimdergisi.Com/Guncel/17-Aralik-Ve-Anti-Kapitalizme -Reaksiyoner-Dusmanlik , (15.01.2015).

Gambetti, Z. (2014). Siyaset Ve Yalan, http://Baslangicdergi.Org/Siyaset-VeYalan-Zeynep-Gambetti/, (4.2.2015).

Hazir, I. (2014, Bahar). Bourdieu Sonrası Yeni Eşitsizlik Gündemleri: Kültürel Sınıf Analizi, Beğeni Ve Kimlik. Cogito, (76): 230-261.

Herman, E. \& Chomsky, N. (1998). Medya Halka Nasil Evet Dedirtir: Kitle İletişim Araçlarının Ekonom Politiği, (Çev. B. Akyoldaş, T. Han, M. Çetin, İ. Kaplan), Minerva Yayınları, İstanbul.

İnsel, A. (Ekim 2011). Bir İktidar Aracı Olarak Terör Kavramı. Birikim, (270).

Kaya, A. (2010). Pierre Bourdieu'nün Pratik Kuramının Kilidi: Alan Kavramı. Ocak Ve Zanaat: Pierre Bourdieu Derlemesi, (Der. G. Çeğin), İletişim Yay, İstanbul, 397-419.

Köse, H. (2004). Bourdieu Medyaya Karşı, Medya:İşbirlikçi, Zorba Ve Çığırtkan, Papirus, İstanbul.

Laçiner, Ö. (Şubat 2014). 17 Aralık Depremi: 30 Mart Seçimleri Ve Akp. Birikim, (298).

Lizardo, O. (2012). Habitus. University Of Notre Dame: http://www3.Nd.Ed u/ Olizardo/Papers/Habitus-Entry.Pdf (4.4.2015).

Mouzelis, N. (2010). Katılımc1-Toplumsal Bütün Sorunu: Parsons, Bourdieu, Giddens. Ocak Ve Zanaat: Pierre Bourdieu Derlemesi, (Der. G. Çeğin), İletişim Yay, İstanbul, 187-266.

Özkirimli, U. (2014). Yeni Türkiye'nin Üç 'Genç Aydın'ı Üzerinden Rakamlarla Yandaşlık. http://www.Diken.Com.Tr/Rakamlarla-Yandaslik, (24.11.2014). 
Özsöz, C. (Bahar 2014). Pierre Bourdieu: Simgesel Şiddet, Eğitim, İktidar. Cogito,(76): 290-311.

Tatlican, Ü. \& Çeğin, G. (2010). Bourdieu Ve Giddens: Habitus Veya Yapının İkiliği. Ocak Ve Zanaat: Pierre Bourdieu Derlemesi, (Der. G. Çeğin), İletişim Yay, İstanbul, 303-366.

Türk, B. (2013). Kanaat Teknisyenliği Dünyasının Yeni Yıldızları: Akp Medyasının Zorlu İkilisi Olarak Rasim Ozan Ve Nagehan Alçı. Birikim, http://www.Birikimdergisi.Com/Guncel/Kanaat-Teknisyenligi-Dunyasi nin-Yeni-Yildizlari-Akp-Medyasinin-Zorlu-İkilisi-Olarak-Rasim.

Türk, B. (Nisan 2012). Akp Ve Kanaat Teknisyenleri. Birikim, (276).

Yildirim, K. (2014). Sağın Dil Hapishanesi, http://www.Birikimdergisi.Com/ Guncel/Sagin-Dil-Hapishanesi, (15.1.2015).

Yildirim, K. (2015). Milli Eskatoloji: Komplo, Kavga Ve Ölüm Gölgesinde Siyaset. http://www.Birikimdergisi.Com/Guncel/Milli-Eskatoloji-Komp lo-Kavga-Ve-Olum-Golgesinde-Siyaset, (13.2.2015). 